Tér és Társadalom 3. évf. 1989/1. 97-100. p.

\title{
KITEKINTÉS
}

FORRAY R. KATALIN:

\section{REGIONÁLIS POLITIKAI STRATÉGIÁK A 90-ES ÉVEK AUSZTRIÁJÁBAN}

„Az oktatáspolitikát, a gazdaságpolitikát és a munkaerö-politikát a jövőben csak regionális politikaként lehet elképzelni és megvalósítani. Ez azt is jelenti, hogy a nemzetközi és országos fejlesztési elképzeléseket regionálisan kell megragadni és megvalósítani. Tudjuk milyen sok függ az új ötletektöl, az új pionírszellemtöl, az új gazdasági fejlesztésektől, amelyek Ausztria peremhelyzetü régióiban új életfeltételeket teremthetnek, lakóinak vonzó jövöt hozhatnak. Ott kell munkahelyet teremteni, ahol az emberek élnek, és mindent meg kell tennünk annak érdekében, hogy a falusi lakosságnak ne kelljen lakóhelyét elhagynia. Ez egyúttal elsőrendü kuitúrpolitikai feladat is." Ezekkel a szavakkal nyitotta meg ILAN KNAPP, az ÖIBF (Osztrák Szakképzéskutató Intézet) igazgatója az intézete által 1988 júniusában szervezett tudományos konferenciát.

Az ÖlBF évente rendez hasonló konferenciákat különbözö, az intézet által kutatott és éppen aktuálisnak mutatkozó témakörökben. A regionális politikák témakörét több tényező is aktuálissá teszi. 1987-ben az Európa Tanács mozgalmat kezdeményezett „Európai kampány a falusias térségekért" elnevezéssel. A 21 európai ország részvétele mutatja, hogy a falusias térségek gazdasági-szociális és ökológiai funkcióinak Európa-szerte nagy jelentöséget tulajdonítanak.

$A z$ osztrák előadásokat hallgatva úgy tünik, nyugati szomszédunk problematikus régiói ugyanazokkal a gondokkal küzdenek, mint a mieink: elvándorlás, idösödö korszerkezet, munkanélküliség, ingázás, az adottságokhoz és szükségletekhez nem eléggé igazodó képzési és gazdasági szerkezet, elmaradott infrastruktúra, a természeti környezet fenyegetettsége stb. Aki csak valamennyire ismeri Ausztria elmaradott agrárvidékeit - ilyennek számit például Burgenland - joggal hökkenhet meg. Ha ez „elmaradottság", és ha ezek a látható feltételek a miénkhez hasonló társadalmi-gazdasági problémákat rejtenek, akkor mennyit kellene áldozni idehaza, hogy az aprófalvas vidékeink nyomorúsága valamelyest is enyhüljön.

A statisztikák - legyen szó a népesség képzettségi szerkezetéröl, foglalkoztatásáról, a terület infrastruktúrájáról, oktatási intézményhálózatáról - imponáló fejlödésröl tanúskodnak Ausztria peremhelyzetü régióiban. Az eredmények javarészt annak köszönhetơk, hogy az ország már közel húsz éve szakitott a spontán fejlödés hitére alapozott kényelmes „passzív segitségnyújtási” politikával. A csaknem két évtizedes politika - a gazdaságilag gyenge szerkezetü, egyoldalúan fejlett térségek kiemelt támogatása - eredménye a látványosan kiépült infrastruktúra, a falusias régiók gazdasági hely- 
zetének javulása. A gazdasági támogatás egyik jelentős formája volt az a gyakorlat, amelyet hazai fogalmainkkal vidéki ipartelepítésnek nevezünk, amelynek során sok új ipari munkahelyet létesítettek az agrárvidékeken.

Ha ennyi a siker, mi indokolja a politika átszabását, új stratégiák kialakítását? A bevezetésben idézett gondolatokból kitưnik, hogy a regionalizmus nemcsak divatjelenség (bár kétségtelenül az is). Az ÖIBF szakmai rangja csak részben indokolja, miért vállaltak részvételt és előadást szövetségi miniszterek, a burgenlandi tartományfönök, a vállalkozói és munkáskamarai vezetók, kutatók és egyetemi professzorok. A részvételt föként a téma magyarázza. A sikerek mellett ugyanis kudarcok is jelentkeztek a regionális politikában, sok problémát nem sikerült megoldani, a változó külső és belső körülmények is új kérdéseket vetnek fel.

Az írásban előzetesen vázolt, élőszóban elhangzott vagy vitában kikristályosodott problémák, érvek, álláspontok töredékét sem lehet egy rövid összefoglalóban elemezni (összel egyébként szokás szerint megjelenik a konferencián elhangzottakat összegzö kötet). Néhány olyan kérdéskört, szempontot emelek csupán ki, amelyek kiemelkedően nagy hangsúlyt kaptak, illetve amelyek a magyar résztvevő - megfigyelő számára kiváltképpen érdekesnek, hasznosnak és talán itthon is adaptálhatónak látszottak.

Az egyik legfontosabb, kemény politikai tényező, amely új regionális politikai stratégia kialakitását sürgeti, Ausztria esetleges belépése a Közös Piacba. Egyelöre e lépés elönyeit és hátrányait elemzik a szakértők és politikusok. Olyan kérdésekre keresnek választ, hogy mi lehet Ausztria szerepe az európai régióban (tranzitország, üdülőország, híd Kelet és Nyugat között); milyen hatást gyakorol a versenyhelyzet az osztrák iparra, mezógazdaságra, a magas szinten kiképzett munkaeröre. E kérdéskörben döntő szerep jut annak, hogyan alakul a Közös Piac és a KGST kölcsönös kapcsolata. Csupán a tájékozódás kedvéért néhány probléma: ha a Közös Piac és a KGST között nem jön létre életképes kapcsolat, Bécs a Közös Piac provinciájává válhat; ha a Duna valódi közlekedési útvonallá fejlődik, Ausztria vonzó lehet a turizmus és piacforgalom szempontjából is, ha azonban ez nem történik meg, Ausztria keleti része elveszti vonzerejét: ha a KGST és a Közös Piac között jól müködö kapcsolat alakul ki, Ausztria nem játszhatja a híd szerepét; a tranzitforgalom anyagi elönyökkel kecsegtet, de súlyosan környezetromboló hatású, kiváltképpen, ha felépül a déli autópálya (ami ellen egyébként falragaszokon tiltakoznak a környezetvédök). Az ilyen és hasonló kérdések különösen érintik Burgenlandot - melynek képviselói érdekes délelötti elöadássorozatban számoltak be és vitatták meg az országrész helyzetét, igen nagy figyelmet szentelve a magyarországi politikai fejleményeknek, plasztikus szavakkal fogalmazva a ,holt határ" részleges megnyílásának. (Bemutatták az első magyar nyelvü Burgenland-térképet is, melynek egyetlen komoly szépséghibája, hogy helységnevek csak németül szerepelnek rajta.) A Közös Piac és a KGST közötti kapcsolatok alakulása Ausztria számára rendkivül fontos kérdés, ezért az ÖIBF következö tudományos ülését ennek a témának tervezi szentelni.

Ami a szükebben vett osztrák regionális politika megújulását illeti, legfontosabbnak számomra az „emberi tényezö" elötérbe kerülése tünik. Húsz éve a szociáldemokraták által kezdeményezett aktív állami támogatás központi tervezói gondolkodás erösödése bizonyos fokú bürokratizálódást eredményezett, a vidéki ipartelepités prog- 
ramjai - az egyenlő esélyek biztosítása érdekében - nem mindig illeszkedtek a regionális adottságokhoz, gyakran az alacsony képzettséget igénylö, viszonylag elmaradott technológiájú üzemek müködtetésével nem alakultak ki a rugalmas alkalmazkođás feltételei, amelyek a versenyképességet növelték volna. Az új politika decentralizálni akar, lényegét ebben a vonatkozásban többen úgy fogalmazták meg, hogy az anyagi támogatás mellett nagyobb szerepet kell kapnia az „inmateriális szubvenciónak”. Empirikus kutatások szerint a modern üzemek telephelyválasztásában nagy szerepe van annak, mennyire hozzáférhetők a jogi, szakmai tanácsadói hálózatok, a dolgozók továbbképzése, a marketing munka. Visszatérő fogalmak az ,információs transzfer", „,technológiai transzfer", az emberi tőke mozgósítását célozzák - persze megfelelő infrastrukturális háttérrel.

Az új gondolkodás a regionális fejlöđés alapvető kritériumának tartja, hogy az érintett régió lakói milyen mértékben kapnak lehetőséget saját sorsukba való beleszólásra. Ez az igazgatás részéról az információk áramoltatásának kötelezettségét jelenti, továbbá olyan körülmények létrehozását, amelyek biztositják a polgárok parlamentáris részvételét lakóhelyüket érintő valamennyi kérdésben. Ezzel szorosan összefügg a törekvés a pozitív lakóhelyi önkép, identitás kialakítására.

A gazdasági kibontakozás alapvető feltételei közé tartozik a magas szintű általános és szakképzés, illetve folyamatos átképzés biztosítása, különösen a fiatal népességnél. A munkanél küliség elsősorban a szakképzetlen fiatalokat fenyegeti, s bár Ausztriának e tekintetben kedvezó a helyzete (a szakképzetlen fiatalok aránya 1970-1988 között 18\%-ról 2\%-ra csökkent az ÖIBF friss adatai szerint), regionális megoszlásuk egyetlen, az átképzés pedig állandó kihivást jelent.

S ez a kérdés kapcsolódik a regionális adottságokhoz igazodó gazdasági fejlődéshez. A saját tartalékaikra támaszkodó, egyúttal környezetkímélő gazdasági fejlesztés számos szép példáját mutatták be a konferencia előadói. Ilyen volt például néhány szomszédos falu asztalosainak szövetkezése, akik megtanulták, hogyan készítsenek modern, minden piacon versenyképes, csak természetes anyagból álló bútorokat. $\mathrm{A}$ hasonló vállalkozásokhoz persze nemcsak megfelelő átképzési rendszer, egyéni vállalkozói szellem szükséges, hanem olyan tanácsadói szervezet - ezt folyamatosan építik ki Ausztria régióiban és kistájain --, amely ötleteket ad, piacot szervez stb. A kisvállalkozások piaci alkalmazkodását Alsó-Ausztria például kereskedőházak létesítésével, valamint - különös tekintettel keleti szomszédaira - szabadkereskedelmi zóna kialakításával szándékozik segiteni.

A legfontosabb cél, hogy a legkisebb községeket, gazdasági és társadalmi egységeket is életképessé tegyék, illetve életképességük megtartásához nyújtsanak segítséget. Ehhez az szükséges, hogy az emberek jólétüket is biztosithassák lakóhelyükön. Ahány régió, annyiféle ötlet, javaslat, példa van arra, hogyan lehet megszervezni a kistelepülések szakorvosi ellátását, a gyermekek óvodai, elemi iskolai nevelését, a kommunális és háztartási szemét elszállitását stb. E kérdések persze - megvitatásuk külön munkacsoport feladata volt - korántsem megoldottak, és sok szempontból a magyarországi problémákat idézik.

ILAN KNAPP összefoglalójában az új regionális politika alábbi jellemzóit, követelményeit hangsúlyozta: a regionális sajátosságokból kibontakozó fejlesztés jelentős nem anyagi támogatással, a pionír szellem és felfelé törekvés terjedése, a döntésekben 


\section{0

való állampolgári részvétel, ưj kreativitás és kockázatvállalás kibontakozása, végül, de nem utolsósorban a szolidáris gondolkodás, tervezés, cselekvés. Ez utóbbi követelmény a városlakókra, a központokban élökre, dolgozókra, a falvakban nemegyszer hétvégi házzal rendelkezőkre vonatkozik، hogy megszünjék, „,a falunak a város által való kizsákmányolása".

Összegezésként a konferencia két tanulságát emelem ki. Az egyik a Magyarország iránti megkülönböztetett érdeklődés, hazánk és Ausztria viszonyának felelős elem. zése, értékelése. Úgy tünt, Magyarország több figyelmet kap nyugati szomszédjától, mint amennyit mi fordítunk Ausztriára. Pedig elég sok tanulni valónk lenne szomszédainktól. A másik megjegyzésem ezzel is összefügg. Ausztriában hallottam az önironikus fogalmat: „Jammerkultur”. Ha a panaszkodás kultúrája a monarchia öröksége, akkor ebből az örökségböl nekünk sokkal több jutott, mint egykori központunknak. A hasonló konferenciákon nálunk megszokott kilátástalan pesszimizmus, a hanyatlás és pusztulás képeinek ecsetelése helyett a problémák konstruktív kezelése volt jellemzö, az elöadások és viták a korábban elkövetett hibák korrekcióját, az itt vagy amott bevált, sikeres gyakorlat elterjesztését, elemzését szolgálták. Ez az optimizmus természetesen nem táplálkozhatik Ausztria kivételesen szerencsés geopolitikai helyzetéböl, forrása a társadalomnak és az egyénnek a saját cselekvőképességébe és jövőjébe vetett hite, közösségi felelósségérzete. Talán elsösorban ezt kellene megtanulnunk szomszédunktól.

KISS ATTILA:

\section{TÉRSZERKEZETI TERMINOLÓGIÁK AUSZTRIÁBAN}

A társadalmi-gazdasági térrel foglalkozó tudományok müvelői - de bizonyára más területeken is hasonló a helyzet - sok esetben ugyanazt a fogalmat egymástól többé-kevésbé eltérö jelenségek megkülönböztetésére használják, illetve ugyanazt a jelenséget más-más kifejezéssel jelölik. A szakmai polémiák gyakran a fogalmak tisztázásával kezdódnek. Nincs ez másképpen Ausztriában sem. A térbeni jelenségek leírása során használatos fogalmak, több-kevesebb átfedéssell, de három terminológiai rendszert épitsenek fel, melyek jelenleg a tudományok osztrảk müvelöi körében használatosak.

Az egyik a „központi helyek” elméletének HANS BOBEK nevével fémjelzett ausztriai adaptációja, a másik a jelenleg is érvényben levő osztrák területrendezési koncepció (ÖRK) modellje és a harmadik a statisztikai összesitések alapját képező - az Osztrák Központi Statisztikai Hivatal által kidolgozott - ún. „városrégiók” rendszere.

Részben elméleti, részben módszertani szempontból nem felesleges - még ha vázlatosan is - a három szisztémát áttekinteni. 